\title{
Subterranean termites diversity in Mianwali District of Punjab, Pakistan
}

\author{
Kausar Fatima ${ }^{1}$, Saima Mustafa ${ }^{1}$, Bilqees Bano ${ }^{1}$, Farkhanda \\ Manzoor $^{2}$, Sana Zahoor ${ }^{3}$, Masroor Ellahi Babar ${ }^{3}$ and Tanveer \\ Hussain $^{3 *}$ \\ 1. Department of Biology, Virtual University of Pakistan, Lahore-Pakistan \\ 2. Department of Zoology, Lahore College for Women University, Lahore-Pakistan \\ 3. Department of Molecular Biology, Virtual University of Pakistan, Lahore-Pakistan \\ *Corresponding author's email: tanveer.hussain@vu.edu.pk \\ Citation
}

Kausar Fatima, Saima Mustafa, Bilqees Bano, Farkhanda Manzoor, Sana Zahoor, Masroor Ellahi Babar and Tanveer Hussain. Subterranean termites diversity in Mianwali District of Punjab, Pakistan. Pure and Applied Biology. Vol. 9, Issue 4, pp2391-2396. http://dx.doi.org/10.19045/bspab.2020.90253

\begin{tabular}{llll}
\hline \hline Received: 00/03/2020 & Revised: 00/05/2020 & Accepted: 00/06/2020 & Online First: 00/06/2020 \\
\hline \hline
\end{tabular}

\section{Abstract}

Subterranean termites cause destruction to the wooden structures and eat cellulose based products all over the world, causing economic loss on large scale. This study is conducted to observe the presence of subterranean termites and their species in district Mianwali Punjab Pakistan, from the months March to August, 2017. Manual method was used to collect the termites from herbs, weeds, shrubs, trees, plant debris, wooden logs and buildings of desert different areas of the District Mianwali. The population density of termites was estimated using Simpson's diversity index equation. For further examination, the preserved (in 80 percent alcohol) termites were carried to Zoology Department, Lahore College for Women University, Lahore, Pakistan. The number of termites was maximum in the months of July and August.Five species of termites Coptotermes heimi (Wasmann),Microtermes mycophagus, Microtermes obesi(Holmgren), Odontotermes guptai and Odontotermes obesi(Ramber), were found in three tehsils of the District Mianwali. The most numerous termite species was $C$. heimi. The diversity and population density of termites in Tehsil Mianwali is more than Tehsil EsaKhel and Tehsil Piplan. The aim of the present study is to evaluate population diversity of termites in District Mianwali.

Keywords: Castes; Cellulose based; Diversity; Simpson's diversity index; Subterranean; Workers

\section{Introduction}

Termites are social insects which live in colonies and consist of different castes. There are divisions of labour among workers, soldiers and reproductive (queen and king). The termite colonies occur in humus, wood debris, timber and other cellulose containing products [1]. They attack on wooden structures, wooden buildings, wooden furniture and paper products [2]. Local environmental factors, vegetation type, temperature, rainfall, and altitudes affect their number or assemblage in any area [3]. In Pakistan, various studies have been conducted to observe the swarming pattern of termites and have correlated it with rainfall and temperature [4]. Fifty species of termites have been recorded from different ecological zones of Pakistan [5]. Keeping in view their diversity and role as pest in different ecological zones of Pakistan, this study is conducted to observe the population density of termites in Mianwali District of Pakistan. The district Mianwali is situated in the south-western part of the Punjab province [6]. Average maximum temperature per annum is $47^{\circ} \mathrm{C}$ and minimum temperature is $19^{\circ} \mathrm{C}$. Mean annual rain fall of the Mianwali is $3.3 \mathrm{~mm}$ and maximum rain fall occurs in the month of July i.e., $6.6 \mathrm{~cm}$ [7]. This study is conducted in keeping in view 
all the environmental factors which affect the distribution and diversity of termites in District Mianwali.

\section{Materials and methods}

Total number of 575 Termites was collected from all three Tehsils of the district Mianwali (Piplan, EsaKhel and Mianwali). The samples were collected manually, by using camel hair brush and wooden sticks. Wooden sticks to collect samples were used in another study by Henderson et al. in 2016 [8]. The pest activity was observed in deserts, riverine areas, pains and hilly area of the District Mianwali. The samples collected were preserved in $80 \%$ alcohol in air tight glass bottles for laboratory studies. These termites were taken to the Department of Zoology, Lahore College for Women University, Pakistan for further lab examination. Their population density was simply estimated by dividing the total number of termites collected, with the area. In the laboratory, termites were further examined to study the different species under microscope. The termites were collected from the months March to August, 2017. Their percentage abundances were calculated in these months. Five different species of termites were examined and their diversity indices in the three Tehsils of District Mianwali were calculated by Simpson's index. Diversity index of number of individuals of five species of termites was also calculated by Simpson's index.

\section{Results}

The external environmental factors including temperature, humidity, texture of soil and wind speed affect the distribution and population density of termites. Population densities of three tehsils varied in accordance with the environmental condition of the areas (Table 1, $2 \& 3$ ). It was observed that Termites were mostly found in the Tehsil Mianwali with 78.29\% by Simpson's diversity index (Table 4). Five termite species were identified from the samples collected from the different areas of the three Tehsils in different months.On Simpson's index high diversity value was observed in August (1-D= $0.7592)$ followed by July $(1-\mathrm{D}=0.7511)$. The termite species Coptotermesheimiwas most abundant in April, June, July and August than other species (Table 5). In July, the number of termites of Microtermes obesus increased and in August, it became the most conspicuous species.. In July and August, the increased pest activity was observed (Fig. 1). Diversity index of number of individuals of five species of termites shows that Coptotermes heimi was the most abundant species found in District Mianwali. Simpson's equation of index shows a value of $\mathrm{D}=0.2266$ of collected sample of termites in district Mianwali. Coptotermes heimi, with a value of $\mathrm{Pi}=$ 0.0954, was more abundant than other species and the least abundant species was Odontotermes guptai with a value of $\mathrm{Pi}=$ 0.0084 and overall the Simpson's Scale diversity of termites was $77 \%$ (Table 6).

Table 1. Population density of termites in Tehsil Piplan, Distric Mianwali

\begin{tabular}{|c|c|c|c|c|c|}
\hline Date & Location & $\begin{array}{c}\text { Area } \\
\text { (sq ft) }\end{array}$ & $\begin{array}{c}\text { Places/ materials } \\
\text { where termites found }\end{array}$ & $\begin{array}{c}\text { Total No. } \\
\text { of termites }\end{array}$ & $\begin{array}{c}\text { Population } \\
\text { Density }\end{array}$ \\
\hline $\begin{array}{c}19-3-2017 \\
29-04-2017 \\
05-05-2017\end{array}$ & $\begin{array}{c}\text { Chak No. 3-4 } \\
\text { ML (Main } \\
\text { Line) }\end{array}$ & 40 & $\begin{array}{c}\text { Playground=33 } \\
\text { Houses=23 } \\
\text { Cotton field=13 }\end{array}$ & 69 & 1.72 \\
\hline $03-06-2017$ & Alu wali & 40 & Dead stem of Kikar=6 & 06 & 0.15 \\
\hline $13-07-2017$ & Musi Wali & 40 & Timber =28 & 28 & 0.7 \\
\hline $19-08-2017$ & $\begin{array}{c}\text { Sargodha U } \\
\text { campus }\end{array}$ & 40 & $\begin{array}{c}\text { Dead Cyprus (Saroo) } \\
\text { tree=13 } \\
\text { Popular dead stem=6 }\end{array}$ & 19 & 0.47 \\
\hline \multicolumn{7}{|c|}{ Total } & 122 & 3.04 \\
\hline
\end{tabular}


Table 2. Popuation density of termites in Tehsil Esa Khel, District Mianwali

\begin{tabular}{|c|c|c|c|c|c|}
\hline Date & Location & $\begin{array}{c}\text { Area } \\
\text { (sq. ft) }\end{array}$ & $\begin{array}{c}\text { Places /materials } \\
\text { Where termites found }\end{array}$ & $\begin{array}{l}\text { Total No. of } \\
\text { Termites }\end{array}$ & $\begin{array}{c}\text { Population } \\
\text { Density }\end{array}$ \\
\hline $16-05-2017$ & Kamar Mushani & 40 & Timber $=42$ & 42 & 1.05 \\
\hline $\begin{array}{l}14-03-2017 \\
09-06-2017\end{array}$ & Tri Khel & 40 & $\begin{array}{l}\text { Living weed }=35 \\
\text { Harmal plant }=21\end{array}$ & 56 & 1.33 \\
\hline 09-07-2017 & $\begin{array}{l}\text { Jinah barrage } \\
\text { Kalabagh }\end{array}$ & 40 & $\begin{array}{c}\text { Living wood of } \\
\text { sheesham }=10 \\
\text { Wooden } \log =26\end{array}$ & 36 & 0.9 \\
\hline 19-08-2017 & Bori khel & 40 & $\begin{array}{c}\text { Wild herb }=26 \\
\text { Kari dead stem }=22 \\
\text { Cow dung }=09 \\
\text { Wild bush }(j a l l)=24\end{array}$ & 81 & 2.02 \\
\hline \multicolumn{4}{|l|}{ Total } & 215 & 4.4 \\
\hline
\end{tabular}

Table 3. Population density of termites in Tehsil Mianwali, District Mianwali

\begin{tabular}{|c|c|c|c|c|c|}
\hline Date & Location & $\begin{array}{l}\text { Area } \\
(\mathrm{sq} \mathbf{f t})\end{array}$ & $\begin{array}{c}\text { Places /material where } \\
\text { termites found }\end{array}$ & $\begin{array}{c}\text { Total No. of } \\
\text { Termites }\end{array}$ & $\begin{array}{c}\text { Population } \\
\text { density }\end{array}$ \\
\hline $\begin{array}{l}23-03-2017 \text { to } \\
03-04-2017\end{array}$ & $\begin{array}{l}\text { Aba } \\
\text { Khel }\end{array}$ & 40 & $\begin{array}{c}\text { Dead Kikar stem }=23 \\
\text { Brick kiln soil }=05 \\
\text { Wild weed }=18 \\
\text { Dead tem of Ak and } \\
\text { Jand }=33\end{array}$ & 79 & 1.97 \\
\hline $\begin{array}{l}03-05-2017 \text { to } \\
11-06-2017\end{array}$ & Chidru & 40 & $\begin{array}{c}\text { Graveyard grass }=10 \\
\text { Dead Kikar stemr }=16 \\
\text { Living stem of Kikar }=06\end{array}$ & 32 & 0.8 \\
\hline 10-07-2017 & Khabari & 40 & $\begin{array}{c}\text { Dead Kikar stem }=10 \\
\text { Peanut shell }=05 \\
\text { Narki }=13 \\
\text { Sharin dead stem }=40\end{array}$ & 68 & 1.7 \\
\hline $18-08-2017$ & $\begin{array}{l}\text { Musa } \\
\text { Khel }\end{array}$ & 40 & $\begin{array}{c}\text { Wild herb(veran, mahori, } \\
\text { boohi) }=11 \\
\text { Wild bush(jall) }=17 \\
\text { Dry grasses }=23 \\
\text { Dead stem of Kikar }=08\end{array}$ & 59 & 1.47 \\
\hline Total & & & & 238 & 5.94 \\
\hline
\end{tabular}

Table 4. Diversity index of number of individuals of five species of termites collected from the three Tehsils of District Mianwali

\begin{tabular}{|c|c|c|c|c|c|c|c|c|c|}
\hline \multirow[t]{2}{*}{ Species } & \multicolumn{3}{|c|}{ Tehsil Piplan } & \multicolumn{3}{|c|}{ Tehsil Isa Khel } & \multicolumn{3}{|c|}{ Tehsil Mianwali } \\
\hline & $\mathbf{N}$ & n-1 & $\mathbf{n}(\mathbf{n}-\mathbf{1})$ & $\mathbf{N}$ & n-1 & n (n-1) & $\mathbf{N}$ & n-1 & $n(n-1)$ \\
\hline Coptotermes heimi & 49 & 48 & 2352 & 62 & 61 & 3782 & 67 & 66 & 4422 \\
\hline Microtermes obesus & 32 & 31 & 992 & 54 & 53 & 2862 & 59 & 58 & 3422 \\
\hline Odontotermes obesus & 18 & 17 & 306 & 41 & 40 & 1640 & 48 & 47 & 2256 \\
\hline $\begin{array}{l}\text { Microtermes } \\
\text { mycophagus }\end{array}$ & 14 & 13 & 182 & 37 & 36 & 1332 & 41 & 40 & 1640 \\
\hline Odontotermesguptai & 09 & 08 & 72 & 21 & 20 & 420 & 23 & 22 & 506 \\
\hline $\begin{array}{c}\text { N (total no. of } \\
\text { species) }\end{array}$ & 122 & - & - & 215 & - & - & 238 & - & - \\
\hline & & \multicolumn{2}{|c|}{$\sum=3904$} & & \multicolumn{2}{|c|}{$\sum=10036$} & & \multicolumn{2}{|c|}{$\sum=12246$} \\
\hline \multicolumn{2}{|c|}{ Simpson's index } & \multicolumn{3}{|c|}{$\begin{array}{c}D=0.2645 \\
1-D=0.7355\end{array}$} & \multicolumn{2}{|c|}{$\begin{array}{c}0.2181 \\
1-\mathrm{D}=0.7819\end{array}$} & \multicolumn{3}{|c|}{$\begin{array}{c}0.2171 \\
1-D=0.7829\end{array}$} \\
\hline
\end{tabular}


Fatima et al.

Table 5. Monthly variation in diversity indices for termites

\begin{tabular}{|c|c|c|c|c|}
\hline Months and name of species & No. Of termites & Percentage & $P i$ & $\mathrm{D}=\sum P i^{2}$ \\
\hline $\begin{array}{c}\text { March } \\
\text { Coptotermes heimi } \\
\text { Microtermes obesus } \\
\text { Odontotermes obesus } \\
\text { Odontotermes guptai } \\
\end{array}$ & $\begin{array}{l}20 \\
24 \\
11 \\
20\end{array}$ & $\begin{array}{c}26.66 \\
32 \\
14.6 \\
26.66 \\
\end{array}$ & $\begin{array}{c}0.2666 \\
0.32 \\
0.1466 \\
0.2666 \\
\end{array}$ & $\begin{array}{l}0.0710 \\
0.1024 \\
0.0214 \\
0.0710 \\
\end{array}$ \\
\hline Odontotermes guptai & 75 & & & $\mathrm{D}=0.2658,1-\mathrm{D}=0.7342$ \\
\hline $\begin{array}{c}\text { April } \\
\text { Coptotermes heimi } \\
\text { Microtermes obesus } \\
\text { Odontotermes obesus } \\
\text { Microtermes mycophagus } \\
\text { Odontotermes guptai } \\
\end{array}$ & $\begin{array}{l}21 \\
12 \\
7 \\
6 \\
6 \\
\end{array}$ & $\begin{array}{l}40.38 \\
23.07 \\
13.46 \\
11.53 \\
11.53 \\
\end{array}$ & $\begin{array}{l}0.4038 \\
0.2307 \\
0.1346 \\
0.1153 \\
0.1153 \\
\end{array}$ & $\begin{array}{r}0.1630 \\
0.0532 \\
0.0181 \\
0.0132 \\
0.0132 \\
\end{array}$ \\
\hline $\begin{array}{c}\text { May } \\
\text { Coptotermes heimi } \\
\text { Microtermes obesus } \\
\text { Odontotermes guptai }\end{array}$ & $\begin{array}{l}12 \\
14 \\
21\end{array}$ & $\begin{array}{l}25.53 \\
29.78 \\
44.68\end{array}$ & $\begin{array}{l}0.2553 \\
0.2978 \\
0.4468\end{array}$ & $\begin{array}{c}\mathrm{D}=0.2607,1-\mathrm{D}=0.7393 \\
0.0651 \\
0.0886 \\
0.1996\end{array}$ \\
\hline Odontotermes guptai & 47 & & & $\mathrm{D}=0.3533,1-\mathrm{D}=0.6467$ \\
\hline $\begin{array}{c}\text { June } \\
\text { Coptotermes heimi } \\
\text { Microtermes obesus } \\
\text { Odontotermes obesus } \\
\text { Microtermes mycophagus }\end{array}$ & $\begin{array}{l}21 \\
6 \\
5 \\
2\end{array}$ & $\begin{array}{c}61.76 \\
17.64 \\
14.70 \\
5.88\end{array}$ & $\begin{array}{l}0.6176 \\
0.1764 \\
0.1470 \\
0.0588\end{array}$ & $\begin{array}{l}0.3814 \\
0.0311 \\
0.0216 \\
0.0034\end{array}$ \\
\hline Microtermes mycophagus & 34 & & & $\mathrm{D}=0.4375,1-\mathrm{D}=0.5625$ \\
\hline $\begin{array}{c}\text { July } \\
\text { Coptotermes heimi } \\
\text { Microtermes obesus } \\
\text { Odontotermes obesus } \\
\text { Microtermes mycophagus } \\
\text { Odontotermes guptai } \\
\end{array}$ & $\begin{array}{c}48 \\
45 \\
43 \\
38 \\
1 \\
\end{array}$ & $\begin{array}{l}27.42 \\
25.71 \\
24.57 \\
21.71 \\
0.571 \\
\end{array}$ & $\begin{array}{l}0.2742 \\
0.2571 \\
0.2457 \\
0.2171 \\
0.0057 \\
\end{array}$ & $\begin{array}{l}0.0751 \\
0.0661 \\
0.0603 \\
0.0471 \\
0.0003 \\
\end{array}$ \\
\hline Odontotermes guptai & 175 & & & $\mathrm{D}=0.2489,1-\mathrm{D}=0.7511$ \\
\hline $\begin{array}{c}\text { August } \\
\text { Coptotermes heimi } \\
\text { Microtermes obesus } \\
\text { Odontotermes obesus } \\
\text { Microtermes mycophagus } \\
\text { Odontotermes guptai }\end{array}$ & $\begin{array}{c}56 \\
44 \\
41 \\
46 \\
5\end{array}$ & $\begin{array}{l}29.16 \\
22.91 \\
21.35 \\
23.95 \\
2.604\end{array}$ & $\begin{array}{l}0.2916 \\
0.2291 \\
0.2135 \\
0.2395 \\
0.0260\end{array}$ & $\begin{array}{l}0.0850 \\
0.0524 \\
0.0455 \\
0.0573 \\
0.0006\end{array}$ \\
\hline Odontotermes guptai & 192 & & & $\mathrm{D}=0.2408,1-\mathrm{D}=0.7592$ \\
\hline
\end{tabular}

Table 6. Diversity index of number of individuals of five species of termites collected

\begin{tabular}{|c|c|c|c|}
\hline Name of species & No. of termites & $\mathbf{P i}$ & $\mathbf{P i}^{\mathbf{2}}$ \\
\hline Coptotermes heimi & 178 & 0.309 & 0.0954 \\
\hline Microtermes obesus & 145 & 0.252 & 0.0635 \\
\hline Odontotermes obesus & 107 & 0.1860 & 0.0343 \\
\hline Microtermes mycophagus & 92 & 0.16 & 0.0254 \\
\hline Odontotermes guptai & 53 & 0.0921 & 0.0084 \\
\hline & 575 & & $\mathrm{D}=0.2266,1-\mathrm{D}=0.7734$ \\
\hline
\end{tabular}




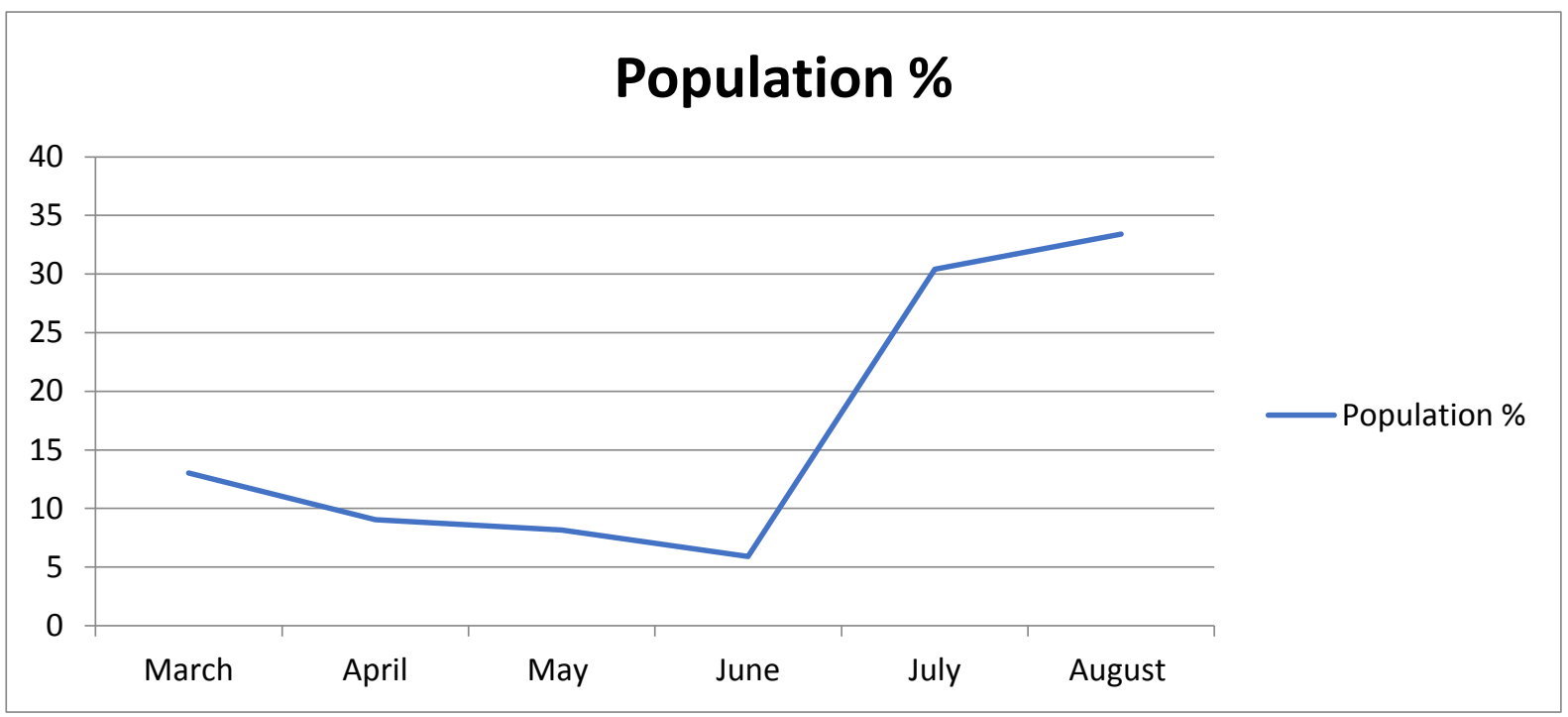

Figure 1. Relative abundance of termites from the months March to August

\section{Discussion}

The analysis of the collected samples of termites from the three tehsils of District Mianwali provides information about the distribution of different species of termites in different habitat and also their abundance ratio in different months. In the present study, by analyzing the collected samples, five termite species,Coptotermes heimi, Microtermes mycophagus, Odontotermes obesus, Microtermes obesus, Odontotermes guptai, were identified. In past very few studies have been conducted on the diversity of the termite species in Pakistan. Four species of termites, Microtermes mycophagus, Microtermes unicolor, Microtermes obesi and Ereterme sparadoxalis were reported from the cotton fields of Multan [9]. From the wheat field of Bahawalpur, Microterme sobesi, Microtermes mycophagus, Odontotermes guptai and Eremetermesparadoxalis were reported $[10,11]$. Data on diversity indices regarding abundance of termites for the first time was provided by Akhtar and Sarwar in 1993 [7]. In the present study, we found $C$. heimi, the most abundant specie, in contrast to the study conducted in Bahawalpur, where the specie $M$. mycophagus was the most dominant than other species [12].

Present study describes that most of the area of Tehsil Piplan is sandy so there is less number of termites as compared to Tehsil Mianwali, with fertile soil. Covering of the ground by the crops, protects the ground and reduces the evaporation of water and increases the humidity of the soil and it is the main factor for providing the habitat for termites [13]. Closer to river Indus and salinity of the soil is not favourable for termites so the density of termite's population is also low in Tehsil Esa Khel than Tehsil Mianwali. Termites are found as decomposers in tropical regions and areas with thick vegetation [14]. Due to availability of thick vegetation, the activity of termites as pests was found maximum in Tehsil Mianwali of District Mianwali than the other two tehsils i.e., Tehsil Piplan and Tehsil EsaKhel.

During the termite collection, $C$. heimi, $O$. besus, O. guptai, M. mycophagus and $M$. Obesus were species, causing damage to wooden structures in houses, stored timber, paper, dead portions of living plants, dead plants, fire wood, soil of grounds, weeds and other cellulose containing materials. Many studies have been conducted to show the decomposing role of termites. It is reported that termites are more important decomposers of wood than fungi [15].

We found maximum numbers of termites in the months of July and August. In July and August, the increased pest activity was observed due to humid and warm environment and heavy rainfall [12]. The relationship between humidity and termites is positive while the atmospheric temperature 
has negative effect on termite's abundance. [16].

\section{Conclusion}

The high density population of termites is associated with the environmental factors of the specified area, which accelerate their reproduction and growth. This study provides useful information about biodiversity of termites in the district Mianwali. It is illustrated that diversity of termites was greater in Mianwali. The present study will be helpful in understanding the biodiversity and pest activity of different termite species in Pakistan.

\section{Authors' contributions}

Conceived and designed the experiments: $\mathrm{T}$ Hussain \& ME Babar, Performed the experiments: K Fatima, Analyzed the data: F Manzoor, B Bano, Contributed materials/ analysis/ tools: F Manzoor, K Fatima, S Zahoor, S Mustafa \& B Bano, Wrote the paper: K Fatima, S Mustafa, B Bano \& T Hussain.

\section{References}

1. Krishna K \& FM Weesner (1970).Taxonomy Phylogeny and Distribution. In: Biology of termites. Academic Press: New York. pp: 643.

2. Akhtar MS (1983). Wood destroying termites (Isoptera) of Pakistan: Key to the most important species, their distribution and pattern of attack. Mater Organismen 1: 277-291.

3. Williams RMC (1966). The East African termites of the genus Cubitermes (Isoptera: Termitidae). Trans $R$ Entomol Soc Lond 118: 73-118.

4. Afzal M (1981). Studies on biology of Bifiditermesbeesoni (Gardner), Ph.D. thesis, Univ. Punjab., Lahore, Pakistan.

5. Akhtar MS (1974). Zoogeography of the termites of Pakistan. Pak J Zool 6: $85-104$.

6. Ahmad I (1964).Vegetation of the salt Range. Pak J For 14(1): 36-64.

7. Akhtar MS, Sarwar M (1993). Comparison of toxicity and repellency of Dieldrin with other insecticides used against Bifiditermes beesoni (Gardner) (Isoptera), Pak J Zool 23: 269-271.

8. Henderson G, Bal K, Gautam KB \& Wang C (2016). Impact of GroundApplied Termiticides on the AboveGround Foraging Behavior of the Formosan Subterranean Termite, Insects 43: 6-7.

9. Akhtar MS \& AS Shahid (1989). Termite populations and damage in cotton fields at Qadarpur, Multan, Pakistan (Isoptera). Sociobiology 15(3): 349-359.

10. Akhtar MS \& M Sarwar (1997). Termite population, diversity and damage in wheat fields of Bahawalpur division. Proc. Pak Congr Zool 17: 153-163.

11. Akhtar MS \& MI Rashid (2001). Studies on population density and diversity of termites of district Bahawalnagar. J Res Sci 12(2): 116122.

12. Ali M, Sial N, Ashraf S and Hasanat A (2013). A survey of subterranean Termite (isoptera) Fauna and its population diversity in district Bahawalpur. Sci Res Essays 11: 289293.

13. Pearce MJ (1997). Termites Biology and Pest Management. CAB International, New York.

14. Davies RG, Eggleton P, Jones DT (2003). Evolution of termite functional diversity: analysis and synthesis of local ecological and regional influences on local species richness. $J$. Biogeogr 30: 847-877.

15. Chudnoff G \& E Goytia (1972). Preservative treatment and service life of fence posts in Puerto Rico. USDA Forest Service Research Paper ITF-12, pp 28.

16. Sattar A \& Saliha Z (2001). Detection and control of subterranean termites. In: Technologies for sustainable Agric. Proc. National Workshop. NIAB. Fsd Pak 24-26: 195-198. 